\title{
異常干渉色に関する一考察
}

\section{A few Comments on Abrormal Interference Colour}

\author{
正田篤五 郎 (Tokugoro Shoda)*
}

結晶に複届折分散がある場合の所湢異常干涉色について，筆者はすでに， 色度図上の軌跡にもとづく型の分類 ${ }^{2}$, 異常干渉色と通裳干涉色との境界 ${ }^{3)}$, 異常干涉色の限界 ${ }^{4)}$ についてのべたが，てれらの計算結果を利用して，末だ 検討のおてなわれていない次の二点について考えてみた。 (1) 可視光のほぼ 中間波長附近において，レターデーション Rの分散直線が傾斜する場合，そ の影響は通常干涉色 ${ }^{1}$ の R が増加する才向に類似してあらわれるか，あるい はその逆にあらわれるか。(2) 鋭敏色板によって薄片の $X^{\prime}, Z^{\prime}$ を汱定する 場含，しばしば相加と相娍とで同様な干涉们を呈し，区別が困難な豩合があ るので, 薄片の回転にともなう色の変化によって，ての区別がなしうるかど うか。

(1)について——可視部のほほ中間波長を $\lambda_{M}$, その $R$ を $\gamma_{M}$ とし, 分散 を近似的に正線と見なし，反時計迴りの傾きを+ $\beta$, 時計廷りのそれを一 $\beta$, 横軸との父りを $\lambda_{0}$ とすれば，以下の第 1 汹一第 6 汹のような色度忷をうる。 第 1 図および第 2 図ではー $R$ と $\boldsymbol{\beta}$ の色軌跡は，ほぼ一致した傾向を示すが, $+R$ と一 $\beta$ のそ机は著しく異る。第 3 図の場合は， $\lambda_{0}=\infty \sim-50 \mathrm{~m} \mu$ ，およ び $\lambda_{0}=\infty \sim+2000 \mathrm{~m} \mu$ の簌罒では，干渉色はほとんど変らず， $550 \mathrm{~m} \mu$ のそ れに近い。第 4 汹は+ $\beta$ の変化による色軦跡と一 $\beta$ のそれとがほとんど一致 した傾向を示す例である。尚，第 $2,5,6$ 脳を比較することにより， $\gamma_{M}=530$ $\mathrm{m} \mu$ とし， $\lambda_{M}$ をかえた場合の様子を知るととができる。 $R$ と $\beta$ の傾问は, $\lambda_{M}=450 \mathrm{~m} \mu$ と $\lambda_{M}=650 \mathrm{~m} \mu$ とでは逆転しているてとがわかる。以上によっ て， $\beta$ の変化とRの変化とが干涉出に及ぼす影響は, 必ずしも一椂でないこ とがわかったが，多くの伯度四を検討した結果，次のことは言えるようであ る。即ち， $\tau_{M}$ を示す点が，一次の色軦跳上にある場合は， $\beta>0$ のをきは,

* 東京大学理学部鉱物学教室 
右あるいは左䢙りの棈円状曲線（一次の色軌跡に近い）を画き $C$ 一点 $\left(\lambda_{0}=0\right.$ に相当する点）に近づく。しかし， $\beta<0$ のときは，乙のような軌跡はとら ない。

（2）について一一欲敏色板を既定の対们位におき，泳片を回伝した場合の 強度 Iは, 第 7 図のポアンカレ図在解いて,

$$
\begin{aligned}
\frac{I}{I_{0}} & =\sin ^{2} \frac{l}{2}=\cos ^{2} 2 \theta \cdot \sin ^{2} \frac{\Delta^{\prime}}{2}+\cos ^{2}\left(\frac{\pi}{4}-\theta\right) \cdot \sin 2 \theta \cdot \sin ^{2} \frac{\Delta+\Delta^{\prime}}{2} \\
& -\sin ^{2}\left(\frac{\pi}{4}-\theta\right) \cdot \sin 2 \theta \cdot \sin ^{2} \frac{\Delta-\Delta^{\prime}}{2}
\end{aligned}
$$

で与えられる。ここに $\theta$ は $X^{\prime}, P$ 間の角， $\Delta, \Delta^{\prime}$ はそれぞれ薄片および検板 の位相差である。

第 8 図の $R, R^{\prime}$ の值に対しては, 上式により, 色軌跡は $R \sim R^{\prime}, R^{\prime}, R$ $+R^{\prime}$ の点を通る直線となり， $R^{\prime}$ よりあ更に純度の高い赤紫色が出現する ことがわかる。第 9 図は, $R=140 \mathrm{~m} \mu(1 / 4$ 波長に近い) の場合で, 大体相 加と相減の中間の色軌跡を画く。Rと $R^{\prime}$ を交换した場合（図の破線）は， $R^{\prime}=140 \mathrm{~m} \mu$ の点から, 色軌跡を回らずに, 直按 $R=680 \mathrm{~m} \mu$ の点に向うこ とがわかる。第10図の破線は, 通常干渉色の出軌跡と, $\theta$ の回転によるそれ とが，逆の倾向を示す例である。以上，薄片を回転する場合の色軌跡は， $R^{\prime}$ の点から通常干涉色の色軌跡のような迁回路を通らず, より近い軌跡に 沿って, 南摆に $R \sim R^{\prime}, R+R^{\prime}$ の点们うことがわかる。従って, 回転に よる $X^{\prime}, Z^{\prime}$ の決定は, 低い干涉色の埸合 (乙の埸合は勿論 $X^{\prime}, Z^{\prime}$ の決定 に薄片回転などを利用する必要はない）以外では，一般に混乱がともなう。

以上，異常干涉色について，常識的に考えると，とかく䛣った結論を生じ やすい二点をあげ，その検討の結果を示した。

終りに，乙の問題に関して與味をよせられた坪井誠太䬦東大名誉教授に深 㴬する。 (1972年 3 月 14 日受理)

\section{文献}

1) Kubota, H. : Proc. Jap. Acad. 36, No. 7, 418-423 (1960)

2) Shoda, T. : Min. Jour. 4, No. 3, 172-202 (1964)

3) Shoda, T. : Min. Jour. 5, No. 1, 1-11 (1966)

4) Shoda, T. : Min. Jour. 6, Nos. 1/2, 46-56 (1969) 


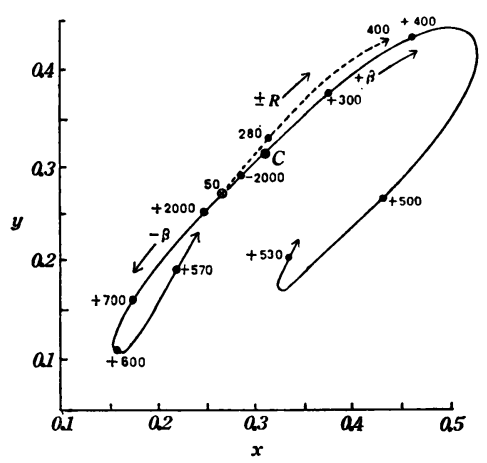

第 1 図 $r_{M}=50 \mathrm{~m} \mu, \lambda_{M}=550 \mathrm{~m} \mu_{\text {。 }}$ 実 線は異常干涉色（数字は $\lambda_{0}$ の 值で $\mathrm{m} \mu$ 単位)。破線は通常干 涉色。以下第 6 図まで標示は同 様。

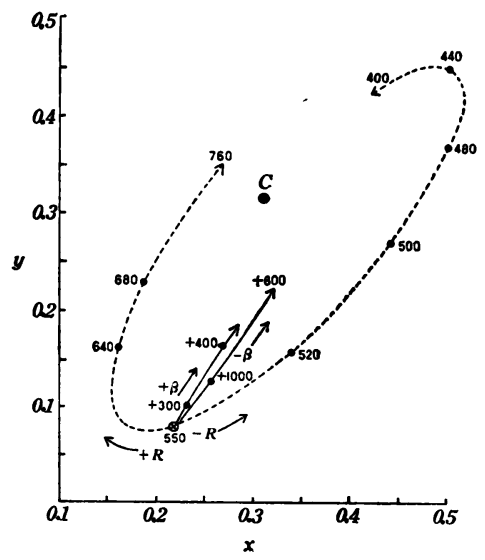

第 3 図 $\gamma_{M}=550 \mathrm{~m} \mu, \lambda_{M}=550 \mathrm{~m} \mu$ 。

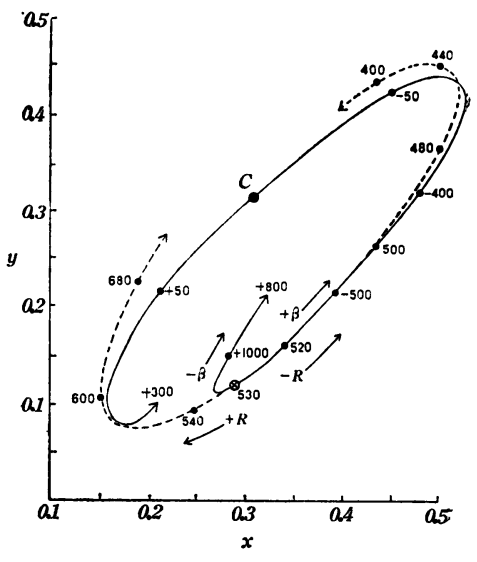

第 2 図 $r_{M}=530 \mathrm{~m} \mu, \lambda_{M}=550 \mathrm{~m} \mu_{\sigma}$

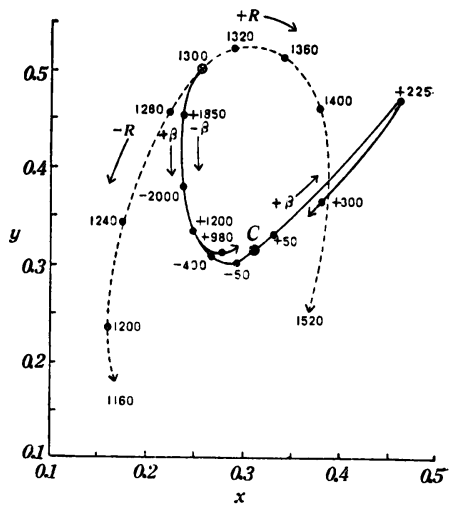

第 4 図 $r_{M}=1300 \mathrm{~m} \mu, \lambda_{M}=550 \mathrm{~m} \mu_{。}$ 


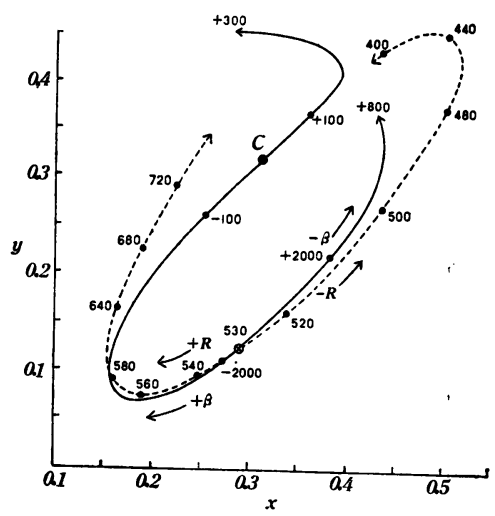

第 5 図 $\gamma_{M}=530 \mathrm{~m} \mu \lambda_{M}=450 \mathrm{~m} \mu_{\text {。 }}$

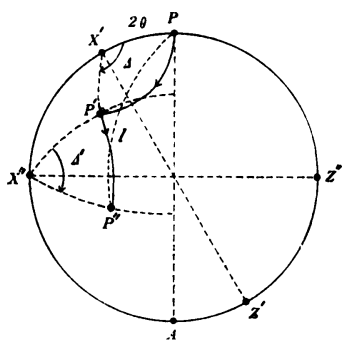

第 7 図 $P, A, X^{\prime}, X^{\prime \prime}$ はそれぞれ polarizer, analyser, 薄片, 検板の振動。 $\Delta, \Delta^{\prime}$ はそれぞ れ薄片および検板の位相差。 $\boldsymbol{\theta}$ は $P X^{\prime}$ 間の角。

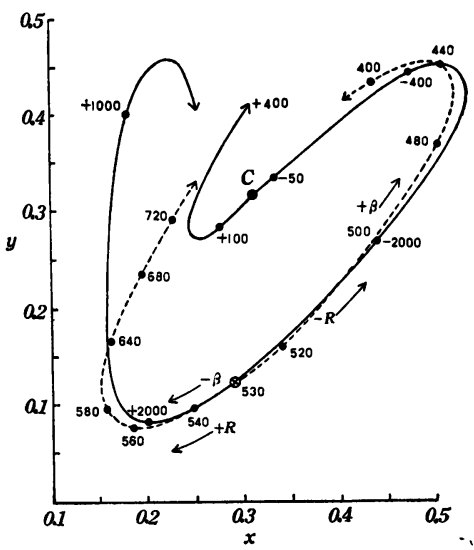

第 6 図 $\gamma_{M}=530 \mathrm{~m} \mu, \lambda_{M}=650 \mathrm{~m} \mu_{\text {。 }}$

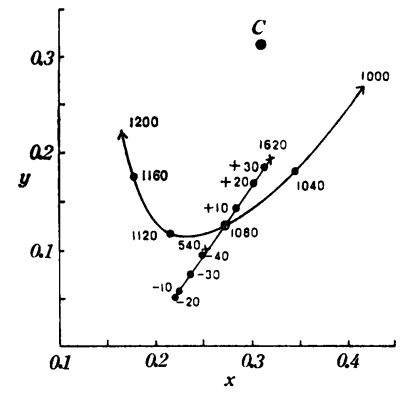

第 8 図 $R=1080 \mathrm{~m} \mu, R^{\prime}=540 \mathrm{~m} \mu$ 。 ,+ 一の数字は $\theta^{\circ}$ の值。以下 第10困まで標示は同様。 


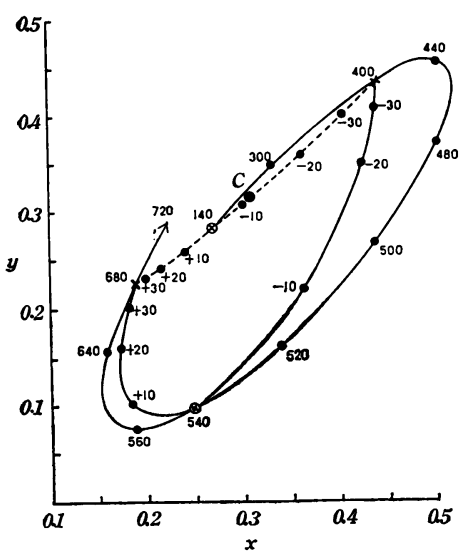

第 9 図実線は通常干渉色および $R=140 \mathrm{~m}, R^{\prime}=540 \mathrm{~m} \mu$ の 異常干涉色。破線 は $R=$ $540 \mathrm{~m} \mu, R^{\prime}=140 \mathrm{~m} \mu$ の異 常干渉色。

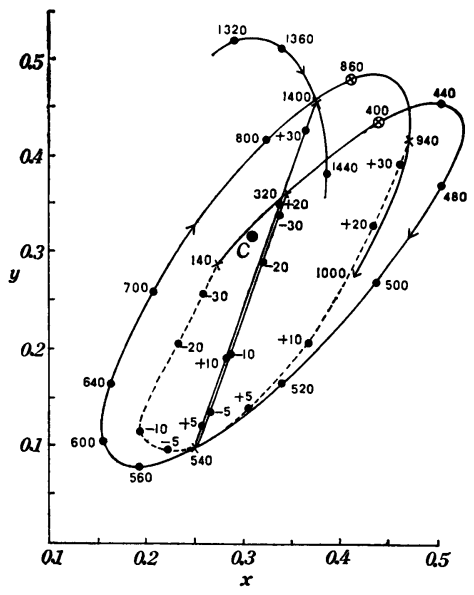

第10図 実線は通常干涉色および $R=$ $860 \mathrm{~m} \mu, R^{\prime}=540 \mathrm{~m} \mu$ の異常干 渉色。破線は $R=400 \mathrm{~m} \mu, R^{\prime}=$ $540 \mathrm{~m} \mu$ の異常干涉色。 